\title{
THEOLOGICAL AND POLEMICAL RECEPTION ON WESTERN SCHOLARSHIP IN AL-QUR'ĀN AND TAFSĪR STUDIES IN INDONESIA
}

\author{
Yusuf Rahman \\ Universitas Islam Negeri Syarif Hidayatullah Jakarta, Indonesia \\ yusuf.rahman@uinjkt.ac.id \\ Article history:
}

Submitted: 22-05-2018 | Revised: 02-07-2018 | Revised: 28-08-2018| Accepted: 30-06-2019

\begin{abstract}
This study aims to examine responses and receptions of Indonesian Muslim scholars on Western non-Muslims scholarship in the study of al-Qur'än and tafsīr. Generally, the reception of their works can be divided into two responses: positive and negative. Yet, this study focuses on negative responses. The findings indicate that the responses are theological and polemical. The main sources of this study are works - printed and online - written by the opponents of Western scholarship in Indonesia. These works are analyzed chronologically to see the reasons behind their rejection. This study shows that Indonesian Muslim scholars responded negatively to Western scholarship on Qur'ānic studies because Western scholars have a hidden agenda in their works. This attitude, the article argues, is very polemical because it essentially generalizes the whole Western scholars have an ulterior motive for destroying Islam and al-Qur'ān. Basically, the research findings state that Western non-Muslim scholars are very diverse, and sometimes even contradictory. Thus, Muslim scholars are expected to participate in enriching Qur'ānic studies by supporting or refuting their findings, or providing new findings.
\end{abstract}

Keywords: Western Scholars, polemical and theological receptions, academic studies of alQur'ān

Abstrak

Artikel ini bertujuan untuk mengkaji bagaimana respon dan resepsi sarjana Muslim Indonesia terhadap kesarjanaan non-Muslim Barat dalam kajian al-Qur'ān dan tafsìr. Secara umum, resepsi terhadap karya-karya mereka bisa dibagi menjadi dua respon: positif dan negatif. Tulisan ini lebih memfokuskan terhadap respon yang bernada negatif, dan berkesimpulan bahwa respon tersebut lebih didasarkan pada alasan teologis dan polemis. Sumber utama tulisan ini adalah karyakarya - baik cetak maupun online - yang ditulis para penentang kesarjanaan Barat di Indonesia. Karya-karya ini dianalisis secara kronologis untuk melihat alasan di balik penolakan mereka.

${ }^{1}$ The initial draft of this article was presented at the International Conference on "New Trends in Qur'ānic Studies" held by Sunan Kalijaga State Islamic University and International Qur'ānic Studies Association (IQSA) in Yogyakarta on August 4-6 2015. This article is part and modification of a more complete article about "Indonesian Muslim Responses to Non-Muslim Approaches to Qur'ānic Studies" which is currently being edited by Mun'im A. Sirry, and prepared for publication by IQSA. 
Kajian ini menunjukkan bahwa sarjana-sarjana Muslim Indonesia yang merespon secara negatif kesarjanaan Barat tentang kajian al-Qur'ān karena mereka menganggap bahwa sarjana Barat memiliki agenda terselubung di dalam karya-karyanya. Sikap tersebut sangat polemis karena secara esensialis menyamaratakan keseluruhan kesarjanaan Barat memiliki motif tersembunyi untuk menghancurkan Islam dan al-Qur'ān. Padahal kesimpulan penelitian sarjana non-Muslim Barat sangat beragam, bahkan kadang bertentangan.Sarjana Muslim diharapkan ikut berpartisipasi dalam memperkaya kajian al-Qur'ān dengan mendukung atau membantah kesimpulan yang ada, atau bahkan mengajukan kesimpulan yang baru.

Kata Kunci: Kesarjanaan Barat; resepsi polemis dan teologis; kajian akademik terhadap al-Qur'ān

\section{Introduction}

The Qur'ān, as the main source of Islam, has been studied by non-Muslim scholars. To find the richness of non-Muslim studies on the Qur'ān, one can find it in The Encyclopaedia of Islam, 2nd Edition (1960-2005) that has been classified, summarized, and well discussed by A.T. Welch. "The Kur'ān," an article written by Welch discusses the subject of the Qur'ān, like the names of al-Qur'ān, the history of al-Qur'ān, the structure and chronology of al-Qur'ān, the linguistic style of al-Qur'ān, the literature of alQur'ān, and the translation of al-Qur'ān. He refers to the classical Islamic sources, contemporary scholarship, and Western scholarly studies.

In 2001-2006, Brill publisher from the Netherlands published 5 volumes + index of special encyclopaedia on the Qur'ānic studies edited by Jane McAuliffe. ${ }^{3}$ It is Encyclopaedia of the Qur'ān that has various themes on al-Qur'ān and its interpretations discussed by scholars, both Muslim and non-Muslim scholars, who are experts in the fields. McAuliffe is one of the female Western scholars, among the few female Western scholars, who pursue Qur'ānic studies. She has written various works including the editing of The Cambridge Companion to the Qur'ān in the year 2006. ${ }^{4}$

\footnotetext{
${ }^{2}$ A.T. Welch, "The Kur'ān," Encyclopaedia of Islam, 2nd Edition, Online (n.d.).

'Jane Dammen McAuliffe, ed., Encyclopaedia of the Qur'ān, vol. I-V (Leiden: Brill, 2001).

${ }^{4}$ Jane Dammen McAuliffe, ed., The Cambridge Companion to
}

The above explanation shows that the works of Western scholars have been developed rapidly. They are written with different approaches, theses and languages, such as English, French, German, Dutch, and other languages. Referring to the growing development of Qur'ānic studies in academic publications and seminars, Gabriel S. Reynolds, Professor at Notre Dame University of the United States, describes that the studies of the Qur'ān in the West can be called 'the Golden Age of Qur'anic studies.' 5

The works of Western scholars are often identified with Orientalist works, while the terms and works of 'Orientalists' have been severely criticized by Edward Said in his book Orientalism in $1979 .{ }^{6}$ Therefore, other terms have emerged, such as non-Muslim studies, Outsider interpretations, ${ }^{7}$ Euro-American scholarship. ${ }^{8}$

the Qur'ān (Cambridge, UK; New York: Cambridge University Press, 2006).

${ }^{5}$ Gabriel Said Reynolds, "Introduction: The Golden Age of Qur'ānic Studies?," in New Perspectives on the Qur'ān: The Qur'ān in Its Historical Context 2, ed. Gabriel Said Reynolds (New York: Routledge, 2011), 1-21. The development of Qur'ānic studies in the West has been discussed at Yusuf Rahman, "Tren Kajian al-Qur'ān di Dunia Barat," Studia Insania 1, no. 1 (2013): 1-8. See Yusuf Rahman, "Survei Bibliografis Kajian al-Qur'ān dan Tafsīr di Barat: Kajian Publikasi Buku Dalam Bahasa Inggris Sejak Tahun 2000an", Journal of Qur'ān and Hadìth Studies 4, no. 1 (2015): 103-127.

${ }^{6}$ Edward Said, Orientalism (New York: Vintage Books, 1979).

${ }^{7}$ Muhammad Abdul-Rauf, "Outsiders' Interpretations of Islam: A Muslim's Point of View," in Approaches to Islam in Religious Studies, ed. Richard C. Martin (Tucson: The University of Arizona Press, 1985), 179-188.

${ }^{8}$ Andrew Rippin, "The Reception of Euro-American Scholarship on the Qur'an and Tafsìr: An Overview 
The use of 'Western scholars' term is indeed quite problematic, because it can also include Muslim scholars who live, teach and write in the West, such as Fazlur Rahman, Nasr Hamid Abu Zayd, Amina Wadud, and others. In this article, the author simplifies the use of Western scholarship to refer to the works of non-Muslim scholars in North America and Europe. The article is written with the intention of examining how Indonesian Muslim scholars respond and receive Western non-Muslims scholarship on the Qur'an and tafsīr.

\section{Muslim Scholars Reception of Western Scholarship on the Qur'ān and Tafsīr}

Muslim scholars have different receptions to Western scholarship: negative and positive. This can be seen, for example, from two Muslim scholars, Muhammad Abdul-Rauf and Fazlur Rahman's writings, on “Outsiders' Interpretation of Islam" in Approaches to Islam in Religious Studies, edited by Richard C. Martin. Abdul-Rauf suggests that it would be better if non-Muslim scholars do not study the Qur'ān, because he finds most of their works are based on "improper accusations and assumptions" so as to produce a false picture of al-Qur'ān. ${ }^{9}$ On the contrary, Rahman emphasizes that non-Muslim scholars could study al-Qur'ān, as long as their studies are not based on prejudice, but with sensitivity and knowledge. ${ }^{10}$ Rahman specifically criticizes the work of John Wansbrough, entitled Quranic Studies, that is full with prejudice and insensitive attitudes to Islam and al-Qur'ān.

However, in general, Muslims respond negatively to the studies of Western scholars towards the Qur'ān, because according to them, these works have raised many doubts about the Qur'ān. S. Parvez Manzoor, one of the editors of

(Editorial Preface)", Journal of Qur'anic Studies 14, no. 1 (April 2012): 1-8.

${ }^{9}$ Abdul-Rauf, "Outsiders' Interpretations of Islam: A Muslim's Point of View," 187.

${ }^{10}$ Fazlur Rahman, "Approaches to Islam in Religious Studies: Review Essay," in Approaches to Islam in Religious Studies, ed. Richard C. Martin (Tucson: The University of Arizona Press, 1985), 197.
Muslim World Book Review, who reviewed the works related to Islamic studies, in his 1987 article entitled "Method against Truth: Orientalism and Qur'ānic Studies,"11 showed his suspicion on Orientalist studies. He wrote:

The Orientalist enterprise of Qur'ān studies, whatever its other merits and services, was a project born of spite, bred in frustration and nourished by vengeance; the spite of the powerful for the powerless, the frustration of the 'rational' towards the 'superstitious' and the vengeance of the 'orthodox' against the 'non-conformist.' 12

Manzoor then argued that the main principle of Orientalist studies is skepticism, it is not to believe everything that Muslims had accepted and believed. ${ }^{13}$

This view was echoed by Muzaffar Iqbal who wrote in 2009 that most Western scholars approached al-Qur'ān with a relativistic and hermeneutical approach that was not in accordance with the basis of al-Qur'ān's divinity. ${ }^{14}$ In another article, this founder and president of the Center for Islam and Science in Canada, criticized the entries and publication of Encyclopaedia of the Qur'ān. According to him this work was based on a relativistic approach to al-Qur'ān. He wrote:

A quick examination of the list of contributors, however, reveals that an overwhelming majority of contributors holds only one foundational perspective on the Qur'ān-

\footnotetext{
${ }^{11}$ S. Parvez Manzoor, "Method against Truth: Orientalism and Qur'anic Studies”, Muslim World Book Review 7 (1987): 3349. This article has been reprinted and published on S. Parvez Manzoor, "Method against Truth: Orientalism and Qur'anic Studies", in The Qur'ān: Style and Content, ed. Andrew Rippin (Aldershot; Burlington; Singapore; Sydney: Ashgate Variorum, 2001), 381-397. This article uses reprint edition.

${ }^{12}$ Manzoor, "Method against Truth: Orientalism and Qur'anic Studies," 381.

${ }^{13}$ Ibid., 385. As will be discussed later, the studies of Western scholars are not monolithic. Even between one scholar and another scholar, they criticize and contradict each other. One scholarly work distinguishes between the work of scholars who have a revisionist approach and a traditionalist approach. See J. Koren and Y.D. Nevo, "Methodological Approaches to Islamic Studies," Der Islam 68 (1991): 87-107. In this case, Manzoor seems to point more criticism at the revisionist group.

${ }^{14}$ Muzaffar Iqbal, "The Qur'an and Its Disbeliever", Islam \& Science 7, no. 2 (2009): 87-126, especially on page 123.
} 
a modernist, relativistic, evolutionary perspective that takes the text of the Qur'àn as a human construction and that calls for a historicist-hermeneutic approach to it. ${ }^{15}$

Therefore, Iqbal and several Muslim scholars published the 'rival' of Encyclopedia of the Qur'an (EQ) under the title Integrated Encyclopedia of the Qur'ān (IEQ). ${ }^{16}$ IEQ is planned to be published in 7 volumes, and in 2016 volume 1 has been published. It begins with entries entitled "Allah," and "Ahmad" (another name for Muhammad), and ends with the entry "Beautiful Names of God."17 Different from other encyclopedias, the entries in IEQ are not based on alphabetical order, at least in the first two entries. To emphasize the highest position of Allah SWT and the Prophet Muhammad in Islam, both are placed in the first and second entries. Only the next entries are arranged according to the alphabetical arrangement of English words or terms. If the authors of these entries are traced further, one finds that all entries are written by Muslim writers - most of them written by Iqbal, the main editor of the $I E Q$, as many as 23 entries out of 47 entries. The choice of only Muslim writers as the contributors has indeed become this $I E Q$ editing policy.

In the introduction, Iqbal compared Qur'ānic studies (this context could also be attributed to Encyclopaedia of the Qur'ān) written by Muslim and non-Muslim scholars. He wrote that if Muslim scholar studies the Qur'ān he or she will approach the Qur'ān as the Book of Revelation and as the Distinguishing Book between the right and the wrong, and as such, he or she will get the rewards and benefits spiritually in this world and in the hereafter. Non-Muslim Western scholar, on

\footnotetext{
${ }^{15}$ Muzaffar Iqbal, "The Qur'ān, Orientalism, and the Encyclopaedia of the Qur'ān', Journal of Qur'ānic Research and Studies 3, no. 5 (2008): 11.

${ }^{16}$ Muzaffar Iqbal, "Integrated Encyclopedia of the Qur'ān: Raison D'etre \& Project Summary," Islam \& Science 8, no. 1 (2010): 33-47.

${ }^{17}$ Muzaffar Iqbal, ed., Integrated Encyclopedia of the Qur'ān (IEQ) (Sherwood Park, Seatlle: Center for Islamic Sciences, 2013).
}

the other hand, after studying the Qur'ān, using anthropological, historical, or other approaches, at the end he or she "refuses to accept the Book of its own terms or respond to the imperatives it expresses." 18 Interestingly, when comparing these two approaches, Iqbal refers to the Qur'ān Surat al-Furqan/25: 53, which illustrates the separation between fresh and seawater with salty bitter seawater. The approach of Muslim scholars represents the fresh and sea water, while that of non-Muslim scholars represents the salty and bitter sea water.

The attribution of this encyclopedia of alQur'ān with the letter I (Integrated) Encyclopedia of the Qur'an (IEQ) also seems to have its own meaning because it can be interpreted as "Islamic" Encyclopedia of the Qur'ān, as a 'rival' against Encyclopaedia of the Qur'an that is not 'Islamic, although initially this encyclopedia was planned to be named The Concise Encyclopedia of the Qur'ān.

The appearance of this $I E Q$ seems to have been predicted by M. Arkoun in his entry in the first volume of $E Q$. He writes:

The project of publishing an Encyclopaedia of the Qur'an that is conceived and realized with respect for the critical order of rational processes is long overdue. This delay confirms this article's position on the historical and epistemological discrepancy between philosophic and scientific reasons, as practiced today in the West and elsewhere, and Islamic reason as it asserts itself in its positions on Islam as well as in political action, legal codes, educational systems and behaviors which encourage the traditional. As long as the Islamic logical universe continues to function within the dogmatic enclosure of its historical form as received since the thirteenth and fourteenth centuries, there will be a place for a parallel Islamic encyclopedia of Islam and, all the more, an Islamic encyclopedia of the Qur'ān. ${ }^{19}$

\footnotetext{
${ }^{18}$ Muzaffar Iqbal, "Introduction," Integrated Encyclopedia of the Qur'ān (2013): xiv.

${ }^{19}$ Mohammed Arkoun, "Contemporary Critical Practices and the Qur'ān", in Encyclopaedia of the Qur'ān, ed. Jane Dammen McAuliffe (Leiden: Brill, 2001), 1: 428.
} 
In his review of IEQ, Rippin considers that as an encyclopedia, IEQ does not fulfill one of the main requirements of encyclopedia, because the existing entries do not at all refer to the wealth of contemporary academic scholarship. It does not refer to the wealth of literature in Western scholarship, and contemporary Muslim scholarship written in Arabic, Persian, Turkish or Indonesian. For Rippin, one principle of an encyclopedia is that each entry shows a wealth of sources and studies that address a particular theme, so that "the sources to speak for themselves and to speak lauder than the author of the entry." 20 Besides, because all authors of the entry come from the same religion, namely Islam, Rippin finds that the tone of the writing is more directed towards Muslim readers. The academic work, on the other hand, should be aimed at a wider audience, regardless of religion. The publication of IEQ, as can be seen, shows the negative receptions of Muslim scholars towards Western scholarship in Qur'ānic studies and tafsīr. They need to make a rival work.

In 2012, Journal of Qur'anic Studies published a special edition discussing the various responses of Muslim scholars to Western scholarship on the Qur'ān and tafsīr, that includes Muslims responses in Turkey, Iran and Arab countries. Mehmet Akif Koc who writes about the influence of Western scholarship on Qur'ānic studes in Turkey, and Morteza Karimi-Nia on contemporary Qur'ānic studies in Iran, argue that Muslim responses to Western scholarship can be classified into apologetic and reformist reception. ${ }^{21}$ Among non-Muslim scholars' studies on the Qur'ān and tafsīr, it is only Toshihiko Izutsu's works that get positive reception. As Ismail Albayrak and

\footnotetext{
${ }^{20}$ Andrew Rippin, "Review of Integrated Encyclopedia of the Qur'an, Vol. 1," Journal of American Oriental Society 136, no. 1 (2016): 223.

${ }^{21}$ Mehmet Akif Koç, "The Influence of Western Qur'anic Scholarship in Turkey", Journal of Qur'anic Studies 14, no. 1 (2012): 9-44, and Morteza Karimi-Nia, “Contemporary Qur'anic Studies in Iran and Its Relationship with Qur'anic Studies in the West," Journal of Qur'anic Studies 14, no. 1 (2012): 45-72.
}

Eisa Al-Akoub have studied, ${ }^{22}$ they argue that Muslims in Turkey and Arab countries respond positively to Izutsu's works. For Albayrak, the main reason for this is because Izutsu was not from the West so he did not have an Orientalist bias. In addition, Izutsu used an empathetic and sympathetic approach to the study of Islam and the Qur'ān.

Unfortunately, this special edition of Journal of Qur'anic Studies does not discuss the reception of Indonesian Muslim scholars towards Western scholarship, even though Indonesia is the largest Sunni Muslim majority country that is different compared to the majority Syi'i Iran. Indonesian Islam is also often referred to as the 'melting pot' and 'meeting pot' ${ }^{23}$ between the Middle Eastern Islamic scholarship tradition and the Western scholarship tradition. Therefore, this article discusses the reception of Indonesian Muslim scholars towards Western scholarship, especially the negative responses.

\section{Negative Reception of Indonesian Muslim Scholars towards Western Scholarship}

Western non-Muslim studies of Islam, including Qur'ānic studies and tafsīr, are introduced as academic subjects at Islamic higher educations in Indonesia. Here, especially at the State Islamic University/UIN (formerly known as the State Institute for Islamic Studies/ IAIN) of Jakarta and Yogyakarta, courses were offered discussing the works of contemporary Muslim scholars and also the works of Western

\footnotetext{
${ }^{22}$ Ismail Albayrak, "The Reception of Toshihiko Izutsu's Qur'anic Studies in the Muslim World: With Special Reference to Turkish Qur'anic Scholarship", Journal of Qur'anic Studies 14, no. 1 (2012): 73-106, and Eisa Al-Akoub, "Izutsu's Study of the Qur'an from an Arab Perspective", Journal of Qur'anic Studies 1 (2012): 107-130.

${ }^{23}$ Adian Husaini, "Kajian Orientalis di UIN Jakarta," last modified 2006, accessed January 1, 2016, http://faisal-wibowo. blogspot.com/2013/01/kajian-orientalis-di-uin-jakarta.html. I could not find the early publication of this article, but it is quite often that Husaini's writings are copied and pasted in many blogs. Husaini has a regular column in www.hidayatullah.com where he usually writes his Weekend Notes (Catatan Akhir Pekan). Accessed 4 Oktober 2016.
} 
scholars, ${ }^{24}$ such as “Modern studies of Al-Qur'ān and Hadith," "Orientalist studies of Al-Qur'ān and Hadith," "Hermeneutics and Semiotics," and others. The subject "Modern Studies of Al-Qur'ān and Hadith," discusses the views and works of modern and contemporary Muslim scholars about the Qur'ān and hadith. This course shows that al-Qur'ān has been interpreted differently by modern Muslim scholars, and that their interpretations are closely related to the context: both the contemporary and interpretive contexts.

The "Orientalist studies of Al-Qur'ān and Hadith" introduces the different approaches of Western scholars in their studies of al-Qur'ān and hadith: the revisionist, the traditionalist, and 'the middle way,' as well as Muslims responses to these approaches. "Hermeneutics and Semiotics" offers students theories of text interpretation from Schleiermacher, Dilthey, Heidegger, Gadamer, Ricoeur, as well as theories of sign, so that students realize the possibility of various kinds of interpreting the text, and the relationship between text, readers, contexts and authors.

The offering of these new courses at IAIN/ UIN has been criticized by some Muslim scholars in Indonesia. Adian Husaini ${ }^{25}$ has been one of IAIN/UIN observers who routinely criticizes the institution. He keeps reminding in his works that Muslims today are living in a period of 'intellectual confrontation' (al-ghazw al-fikrī), a term he took from his teacher, Muhammad Naquib al-Attas. ${ }^{26} \mathrm{He}$ emphasizes that the

\footnotetext{
${ }^{24}$ Izza Rohman does not agree to link the emergence of a new approach in the Qur'anic study with Western scholarship. $\mathrm{He}$ states that there are many other factors that influence the emergence of this new approach. See Rohman, "New Approaches in Interpreting the Qur'an in Contemporary Indonesia," 208. However, I argue that the social, historical, contextual and critical approaches to the Qur'an, except for a very normative thematic approach, are mainly influenced by the Qur'anic scholarship developed in the West.

${ }^{25}$ Husaini's educational background is very diverse. He took a bachelor program at the Faculty of Veterinary Medicine IPB, then Master in International Relations at Jayabaya University, and Ph.D. at ISTAC-IIUM.

${ }^{26}$ Adian Husaini, Wajah Peradaban Barat: Dari Hegemoni Kristen Ke Dominasi Sekular-Liberal (Jakarta: Gema Insani Press, 2005), see page xxi. See also chapter "Islam dan Barat: A
}

Western thought has infiltrated Islamic thought, and this 'liberal virus' 27 then is introduced in Islamic higher education. He is very frustrated to see Western scholarship and the works of liberal and secular Muslim scholars, that have been influenced by the West, are introduced and taught in Islamic higher education.

For instance, after paying attention to the curriculum of “Orientalist Studies of Al-Qur'ān and Hadith" in Tafsir-Hadits Department of Ushuluddin Faculty UIN Jakarta, Husaini writes:

The case of curriculum at Tafsir-Hadith Department of UIN Jakarta is a clear evidence; the infiltration of orientalism in Islamic studies at Islamic universities has gripped Muslim scholars. This is very ironic. In fact, orientalist studies on al-Qur'an have proven to contain various irregularities. ${ }^{28}$

To emphasize this intellectual confrontation, in another article, Weekend Notes at www. hidayatullah.com, which criticizes the course of Hermeneutics, Husaini states that the offering of the course is one kind of 'Christian infiltration,' ${ }^{29}$ because it is a method of the Jews and Christians in understanding the Bible. Finally, in his article "Problems with the Text of the Bible and Hermeneutics," he argues that hermeneutics is part of "secularism and liberalism hegemony" 0 and originates from religious and cultural

Permanent Confrontation," 231ff.

${ }^{27}$ Adian Husaini, Hegemoni Kristen-Barat Dalam Studi Islam Di Perguruan Tinggi (Jakarta: Gema Insani Press, 2006); Adian Husaini, Virus Liberalisme Di Perguruan Tinggi Islam (Jakarta: Gema Insani Press, 2009).

${ }^{28}$ Adian Husaini, "Kajian Orientalis at UIN Jakarta," last modified 2006, accessed January 1, 2016, http://faisal-wibowo.blogspot. com/2013/01/kajian-orientalis-di-uin-jakarta.html. I do not get information on where this article was first published. However, it is very often happened that Husaini's and other writings are copied and pasted and shared on various existing blogs. Husaini has a column on www.hidayatullah.com where he always writes CAP (Catatan Akhir Pekan). Accessed October 4, 2016.

${ }^{29}$ Adian Husaini, "Hermeneutika Dan Infiltrasi Kristen," last modified 2004, accessed October 4, 2016, http:// www.hidayatullah.com/kolom/catatan-akhir-pekan/ $\mathrm{read} / 2004 / 04 / 03 / 2486 /$ hermeneutika-dan-infiltrasi-kristen.html Diakses 4 Oktober 2016.

${ }^{30}$ Adian Husaini, "Problem Teks Bible dan Hermeneutika," Islamia 1, no. 1 (2004), terutama 14. 
traditions that are different from Islamic religious traditions. Therefore, it cannot be followed.

Husayni's comments appear full of al-ghazw al-fikri argument, where everything is simplified or dramatized as a conflict of thought between Islam/Muslim and Christian-Jewish, with orientalism as a cover for infiltrating Jewish and Christian thought. Thus, his works can be considered as polemical works. In supporting his criticism of Orientalist works, Husaini refers to and upholds the work of Muhammad Muștafā A 'z̧amī (Azami), entitled The History of Qur'ānic Text, ${ }^{31}$, which he believes has succeeded in refuting the Orientalist argument. Unfortunately, Azami's work is also very polemical and prejudiced. When commenting on Orientalist works, Azami states:

The central point, which must be made clear, is that there is a definite motive behind all these 'discoveries'. Such findings do not exist in a vacuum or fall unexpectedly into the scholar's lap; they are the brainchild of a particular ideological and political arena, served up in the guise of breakthrough academic research. Attempts to distort Islam and its sacred texts are in fact as old as the religion itself, though the strategy behind these efforts has fluctuated according to the intended goal. ${ }^{32}$

Azami's view was very biased and polemical by stating that all works of Western scholars have ideological and political motives. This view is also present in Manzoor's and Iqbal's point of view towards Western scholarship. Unfortunately, this view is also found in the responses of Indonesian Muslim scholars to the works of Western scholars on al-Qur'ān. Karimi-Nia classifies this negative response as "theological and polemical receptions." 33

Syamsuddin Arif, for instance, in his book Orientalis \& Diabolism Thought, portrays Western

\footnotetext{
${ }^{31}$ M.M. Azami, The History of the Qur' annic Text: From Revelation to Compilation (Leicester: UK Islamc Academy, 2003).

${ }^{32}$ Azami, The History of the Qur'ānic Text: From Revelation to Compilation, 8 .

${ }^{33}$ Karimi-Nia, "Contemporary Qur'anic Studies in Iran and Its Relationship with Qur'anic Studies in the West," 61.
}

scholarship on Qur'ān, such as Noldeke, Mingana, Wansbrough, originated from skepticism towards al-Qur'ān. Arif notes that "Contrary with Muslim scholars, Western Orientalists start from prejudice and doubt, and they will end with doubt." 34

In Western scholarship, this approach can be classified as a Revisionist approach, which is different from the Traditionalist approach. In 2015, Mun'im A. Sirry published Kontroversi Islam Awal: Antara Mazhab Tradisionalis dan Revisionis, ${ }^{35}$ explaining at least four approaches to Early Islam: descriptive approach, source criticism approach, traditional criticism approach, and skeptic approach. However, Arif does not distinguish between these various approaches in Western scholarship, as if they are all the same in approaching the Qur'ān.

Western scholars have debated the reliability and historicity of Islamic sources, especially the sources of Early Islam, which have many contradictions, and mostly reflect the historical context when the works were written but then projected into early period. ${ }^{36}$ As a data, these sources are historically problematic for them. Therefore, Western scholars are divided into two groups: the Traditionalist groups who accept these sources as they are (descriptive approach), and the Revisionist groups, comprising those who are critical of those sources (source criticism and tradition approaches) and skeptics who do not accept these sources (skeptic approach).

Most Muslim scholars when criticizing Western scholarship only refer to this radical revisionist group, and do not mention other scholars from the other groups, such as A. Welch, D. Madigan, and K. Cragg. One of Arif's arguments in his rebuttal to Western scholarship is the verse of the Qur'ān (Q. 2:120 “wa lan tard̄a 'anka l-yahūdu wa lā n-nașārā hattā tattabi"

\footnotetext{
${ }^{34}$ Syamsuddin Arif, Orientalis \& Diabolisme Pemikiran (Jakarta: Gema Insani Press, 2008), 23.

${ }^{35}$ Mun'im A. Sirry, Kontroversi Islam Awal: Antara Mazhab Tradisionalis Dan Revisionis (Bandung: Mizan, 2015).

${ }^{36}$ Ibid., 15.
} 
millatahum" (The Jews and Christians will not be satisfied with you until you follow their religion). ${ }^{37}$ This is for Arif to assert that Orientalists - Jews and Christians - have a veiled agenda to destroy Islam and they will continue to do so. This verse was also reiterated by Arif in a general lecture presented at the International Institute of Islamic Thought and Civilization in May 2010 entitled "The Challenge of Orientalist in Islamic Thought" which is available on YouTube. ${ }^{38}$

Thus, their criticism of Western scholars' works is more nuanced theologically, not academically and scientifically. Looking at the three propositions advanced by Azami, to whom the opponents of Western scholarship usually refer, in the study of the Qur'ān, one will find this polemical and theological attitude. The first proposition "The Qur'ān is the very word of Allah, his final message to all humanity, revealed to His final messenger Muhammad and transcending all limitations of time and space. It is preserved in its original tongue without any amendments, additions, or deletions." 39 This statement is a theological view believed by Muslims. The question is, is it wrong if this statement is reviewed academically? For example, does Mushaf al-Qur'ān today contains all the revelations received by the Prophet Muhammad? Is there, in the process of compiling the mushaf Uthmān, some verses were discarded or deleted? Here are some academic questions, which have been posed by the classical Muslim scholars as is evident in the literature of 'ulüm al-Qur'ān, that invite modern and contemporary scholars to analyze philologically the various manuscripts of Mushaf al-Qur'ān. Unfortunately, when they ask

\footnotetext{
${ }^{37}$ Arif, Orientalis \& Diabolisme Pemikiran, 21.

${ }^{38} \mathrm{https}: / / \mathrm{www}$. youtube.com/watch? $\mathrm{v}=\mathrm{QZW} 7 \mathrm{~W} 1 \mathrm{UH7L} 0 . \quad$ In the public lecture, Arif explained the history of Orientalists, the Orientalist figures, a nd the a pproaches a nd methodology used by Orientalists. Most of the scholars referred to in the presentation were the Revisionist scholars, such as Goldziher, Schacht, Wansbrough, Crone, etc. This is to argue for the danger of Orientalists.

${ }^{39}$ Azami, The History of the Qur'annic Text: From Revelation to Compilation, 13.
}

these questions academically, they are accused of not respecting Islam and al-Qur'ān.

The resistance to this kind of study appears in the second proposition of Azami: "There will never be a discovery of a Qur'ān, fragmented or whole, which differs from the consensus text circulating throughout the world. If it does differ then it cannot be regarded as Qur'ān, because one of the foremost conditions for accepting anything as such is that it conforms to the text used in Uthmān's Muṣhaf." ${ }^{40}$ This proposition can negate scholars' work who study the manuscript that have been found, and discuss the history of Al-Qur'ān text. One of the most persistent effort is an institution led by Angelika Neuwirth, the Corpus Coranicum Project, which has collected several manuscripts of al-Qur'ān. ${ }^{41}$ Besides, there are also German scholars who have found manuscripts, including in this case the manuscripts of Mushaf al-Qur'ān discovered by German and Yemeni scholars in the 1970s at Șan'à' Yaman Mosque. ${ }^{42}$ Behnam Sadeghi has conducted several studies of the existing manuscripts, ${ }^{43}$ comparing manuscripts of muṣhaf Șan'ā', with muṣhaf 'Uthmānī, mușhaf Ibn Mas'ūd, and Ubayy b. $\mathrm{Ka}$ 'b, to "illuminate the state of the text prior to the branching off of these various traditions. It can shed light on the progenitor of all textual traditions, the Qur'ānic prototype." 44

Furthermore, those studies cannot be accepted by Azmi if it is contrary or different from mușhaf 'Uthmānī, especially when referring to the third Azami's proposition. For him "only a devout

\footnotetext{
${ }^{40}$ Ibid.

${ }^{41}$ About Corpus Coranicum, lihat Oliver Leaman, "The Corpus Coranicum Project and the Issue of Novelty," Journal of Qur'anic Studies 15, no. 2 (2013): 142-148.

${ }^{42}$ About manuscript mușhaf al-Qur'ān founded by Șan'ā', See Behnam Sadeghi and Mohsen Goudarzi, "Șan'ā' 1 and the Origins of the Qur'ān,” Der Islam 87, no. 1-2 (2012): 1-129.

${ }^{43}$ Ibid.; Behnam Sadeghi and Uwe Bergmann, "The Codex of a Companion of the Prophet and the Qur'ân of the Prophet," Arabica 57 (2010): 343-436; Behnam Sadeghi and Uwe Bergmann, "The Codex of a Companion of the Prophet and the Qur'ān of the Prophet. Corrigenda," Arabica 57 (2010): 516516.

${ }^{44}$ Sadeghi and Bergmann, "The Codex of a Companion of the Prophet and the Qur'ān of the Prophet," 311.
} 
Muslim has the legitimate prerogative to write on Islamic and its related subjects." ${ }^{45}$ This statement does not provide any space for non-Muslim scholars to conduct studies on the Qur'ān, or even if they do, their studies will be automatically incorrect and invalid, because the validity belongs to the studies of Muslim scholars. Validity criteria is determined by faith not by scientific studies that can be accounted for academically.

However, these outlooks and propositions represent Muslim scholars' guidelines to respond to Western scholarship negatively. This attitude is also agreed by Indonesian Muslim scholars. It is for this reason, Azami's work The History of Qur'anic Text is then translated into Indonesian.

As Sirry has insisted, Western scholars are not monolithic and each has a different approach and thesis. Karimi-Nia reasons that one of the criteria to classify the works of the opponents of Western scholarship as polemical work is:

"[They] always presuppose that the Westerners are a monolithic entity with singular sinister motives. They do not understand that in the West, and among Western scholars of Islam, there are disparate principles, methodologies and results which have led to the emergence of various schools of Islamic studies." 46

Indeed, those who receive negatively the works of Western scholars recognize the development of Western scholarly studies of Islam, including the study of al-Qur'ān. Hamid Fahmy Zarkasyi in his article entitled "Tradisi Orientalisme dan Framework Studi al-Qur'ān," ${ }^{47}$ describes the phases of orientalism development from the sixteenth century to the Second World War. But for Zarkasyi, all forms and phases of orientalism have the same goal "anti-Islamic spirit, [which] in its development of anti-Islamic was then reduced and replaced with approaches that use logic,

\footnotetext{
${ }^{45}$ Azami, The History of the Qur'anic Text: From Revelation to Compilation, 13.

${ }^{46}$ Karimi-Nia, "Contemporary Qur'anic Studies in Iran and Its Relationship with Qur'anic Studies in the West," 61.

${ }^{47}$ Hamid Fahmy Zarkasyi, "Tradisi Orientalisme Dan Framework Studi Al-Qur'an,” Tsaqafah 7, no. 1 (2011): 1-30.
}

knowledge and argumentation." 48 He further emphasizes that "although it is scientific and seemingly objective, the framework of orientalist studies cannot be separated from the color and background of religion, politics, worldview and the values of Western civilization." ${ }^{\prime 4}$

'Worldview,' that is the key word that Zarkasyi always uses when he opposes Western thought, as Husaini uses the term al-ghazw alfikrī. Zarkas yi argues that Western scholarship needs to be watched out because it is based on the Western worldview, which is very different from the Islamic worldview. For him, the worldview of Islam consists of the concepts of God, the Prophet, man, life, the world and others, which are not appropriate with Western worldview. ${ }^{50}$ The Western view of life was developed by European society to encompass Roman and Greek civilizations as well as European civilization, Judaism and Christianity. Following his mentor's view Syed Naquib al-Attas, Zarkasyi, himself an ISTAC alumni in $2006,{ }^{51}$ emphasizes that Islamic worldview centered on the concept of the oneness of God, based on revelation and reason, and colored by the method of thought that is tauhidik..$^{52}$ Therefore, Western scholarship cannot be adopted and implemented in Islamic studies. Zarkasyi warned that "each [worldview] has its own character and elements. If the elements of a worldview are inserted with another element, there will be confusion." 53

In concluding his "Tradition of Orientalism and the Frame work Study of Al-Qur'ān,"

\footnotetext{
${ }^{48}$ Ibid., 7.

${ }^{49}$ Ibid.

${ }^{50}$ Hamid Fahmy Zarkasyi, "Mendudukkan Orientalis," in Misykat: Refleksi Tentang Islam, Westernisasi \& Liberalisasi (Jakarta: INSISTS, 2012), 69dst.

${ }^{51}$ Zarkasyi graduated from Institut Studi Islam Darussalam Gontor Ponorogo. He then got two Masters degrees: First M.Ed from University Punjab, Lahore (1986), dan M.Phil in Islamic study at University of Birmingham (1998). 2006 he obtained a doctorate from ISTAC in Islamic studies with a dissertation on the Concept of Causality according to al-Ghazali.

${ }^{52}$ Hamid Fahmy Zarkasyi, "Worldview Islam dan Kapitalisme Barat," Tsaqafah 9, no. 1 (2013): See 24.

${ }^{53}$ Hamid Fahmy Zarkasyi, “Barat," Islamia 1, no. 1 (2004): 119.
} 
Zarkasyi writes:

Orientalist $[\mathrm{u}]$ nderstanding of Islam is driven by certain motives which are full of Western interests. Likewise their study of the history of Al-Qur'ān, its compilation process, its ontological status, its content and methodology are influenced by the secular Western scientific approach and colored by the beliefs and traditions of Christianity and Judaism. $^{54}$

This conclusion is very biased and polemical. It seems that Zarkasyi was greatly influenced by Said, thus believing in Said's conclusion that "whatever European [sic] people say about the East is still racial, imperialist and ethnocentric." 55 But many scholars have reviewed Orientalism, with various criticisms and appreciations, and they also find that Said's work is a polemical book. ${ }^{56}$ One reason is because Said is essentially categorizing Orientalists as a whole as having been misrepresenting the Orient as a whole. "If Said claims that Orientalism created the false essence of an Orient [...]," Daniel Martin Varisco also criticizes Said's work by saying that "Said himself created a false essence of Orientalism...." 57

This is one of the risks of essentialism, which perceives things simply in black and white, and places them in two contradictory positions: West and East, Western and Islamic civilization, Western scholarship based on Christian and Judaic hegemony and Islamic scholarship based on revelation, as if there are no complexities and variations in each of them.

It must be acknowledged that each has its/his/ her own biases, subjectivities, and assumptions which are influenced by their respective cultures and traditions. These biases might be difficult to be eliminated but can be reduced. Varisco proposes the way to reduce the biases with

\footnotetext{
${ }^{54}$ Zarkasyi, "Tradisi Orientalisme dan Framework Studi AlQur'an," 26.

${ }^{55}$ Ibid., 7.

${ }^{56}$ Daniel Martin Varisco, Reading Orientalism: Said and the Unsaid (Seattle: University of Washington Press, 2007).

${ }^{57}$ Ibid., 292.
}

"civil academic debate" and "sound academic scholarship." He states:

Moving beyond the East-West binary requires an academic approach that emphasizes the continued improvement of methods to reach a less biased representation of the other while recognizing the inevitable ethnocentricity in us all. Moving beyond the politics of blame requires a switch from the rhetoric of polemic to civil academic debate with a measure of intellectual tolerance for opposing viewpoints. ${ }^{58}$

It cannot be denied that some works of Western scholars are also biased and polemical. Rippin even indicates the emergence of "pseudoacademic Islamophobic approaches to the Qur'an,"59 such as the works of Ibn Warraq and Christopher Luxenberg. It is to be noted that these two scholars, along with Karl-Heinz Ohlig, ${ }^{60}$ participated in Inarah Institute for Research of Early Islamic History and Quran group in Germany, which has "unconventional revisionist interpretations of the origins of Islam and the Qur'ān."

Such works have been criticized by other Western scholars in the framework of "scholarly discourse" by proposing various academic methodologies and theses which are supported by historical arguments and evidences. Although each has a different methodology and thesis, the studies of the Qur'ān and tafsīr in the West continue to develop, because, as Reynolds confirms in the introduction to his book New Perspectives on the Qur'ān:

$[\mathrm{R}]$ ecent critical scholarship to the text on the Qur'ān has been largely shaped by a sympathetic response to the text of the Qur'ān

\footnotetext{
${ }^{58}$ Ibid., 302.

${ }^{59}$ Rippin, "The Reception of Euro-American Scholarship on the Qur'an and Tafsìr," 3. In his other article, Rippin mentions that their works represents "major dangers to the integrity and the academic success of the discipline."; Rippin, "“Western Scholarship and the Qur'ān," in Cambridge Companion to the Qur'ān, ed. Jane Dammen McAuliffe (Cambridge: Cambridge University Press, 2006), 235-251, especially 246.

${ }^{60}$ Not surprisingly, their works are criticized by Zarkasyi. See Zarkasyi, "The Tradition of Orientalism and the Framework of the Study of the Qur'an."
} 
itself. Instead of polemic, scholars involved in this movement are generally motivated by intellectual appreciation, even fascination to the text of the Qur'ān itself. ${ }^{61}$

In this context, Muslim scholars, like Abdullah Saeed, Walid Saleh, Emran Badawi, and our own Mun'im Sirry, have been involved and participated in academic seminars and also publications on Qur'ān and tafsīr studies, and also contributed to 'the golden age of Qur'ānic studies' in the West.' This condition will continue to develop as long as Muslim scholars are willing to participate in this academic discourse, and distance themselves from theological and polemical normative responses.

If one reads more closely the negative responses to Western scholarship, one finds that these receptions are generally more focused on Qur'ānic studies. Zarkasyi in his article entitled "The Tradition of Orientalism and Qur'ānic Study Framework" criticizes 5 models of Western scholarly studies, closely related to Qur'ānic studies. Even when reviewing the studies of Qur'ānic content, he highlights the studies which affirm "the content of al-Qur'ān from Judeo and Christian sources."

In fact, Western scholarship in the study of tafsīr is remarkable. For instance, Mustafa Shah has edited 4 volumes Tafsir: Interpreting the Qur'an ${ }^{62}$ containing 81 articles, some of which was published in 1967. When reviewing this book, Rippin believes that the study of tafsīr has become "an established sub-discipline."63 The articles in the first volume of the book discuss tafsīr in the Early Period of Islam, the second volume on procedures and interpretation tools, and finally, Tafsir of Sunnī and Sȳ̄'̄̄ and Tafsir in the classical to the modern times in the third

\footnotetext{
${ }^{61}$ Reynolds, “Introduction: The Golden Age of Qur'ānic Studies?", Page 21.

${ }^{62}$ Mustafa Shah, ed., Tafsir Interpreting the Qur'an Vol. 1 Part 1: History and Development (London and New York: Routledge, 2013). ${ }^{63}$ Andrew Rippin, "Review of Tafsir: Interpreting the Qur'ān Edited by Mustafa Shah," Journal of Qur'anic Studies (2013): 162-165.
}

and fourth volumes respectively. The majority of the writers are Western scholars. This shows again the richness of Western scholarly studies that invites the involvement of Muslim scholars to participate in enriching the scholarship of alQur'ān and tafsīr in the West.

\section{Conclusion}

From this discussion, it is quite clear that Indonesian Muslim scholars respond negatively to Western scholarship on Qur'ānic studies because they consider that Western scholars have a hidden agenda in their works. They warned of a clash or conflict of thought (ghazw al-fikr) between Western thought and Islam, and the risk of Western worldview on Islamic worldview.

This study shows that this attitude is very polemical because it essentially generalizes the whole Western scholarship has an ulterior motive for destroying Islam and al-Qur'ān. However, in reality, the conclusions reached by Western non-Muslim scholars are very diverse, sometimes contradictory. Muslim scholars are expected to participate in enriching Qur'ānic studies by supporting or refuting their theses or even putting forward a new thesis, but they are still adhered to the 'sound academic scholarship.'

\section{References}

Abdul-Rauf, Muhammad. "Outsiders' Interpretations of Islam: A Muslim's Point of View." In Approaches to Islam in Religious Studies, edited by Richard C. Martin, 179-188. Tucson: The University of Arizona Press, 1985.

Al-Akoub, Eisa. 'Izutsu's Study of the Qur'an from an Arab Perspective." Journal of Qur'anic Studies 1 (2012): 107-130.

Albayrak, Ismail. "The Reception of Toshihiko Izutsu's Qur'anic Studies in the Muslim World: With Special Reference to Turkish 
Qur'anic Scholarship." Journal of Qur'anic Studies 14, no. 1 (2012): 73-106.

Arif, Syamsuddin. Orientalis \& Diabolisme Pemikiran. Jakarta: Gema Insani Press, 2008.

Arkoun, Mohammed. "Contemporary Critical Practices and the Qur'an." In Encyclopaedia of the Qur'an, edited by Jane Dammen McAuliffe, 412-430. Leiden: Brill, 2001.

Azami, M.M. The History of Qur'anic Text. Sejarah Teks Al-Qur'an: Dari Wahyu Sampai Kompilasi. Jakarta: Gema Insani Press, 2005.

. The History of the Qur'annic Text: From Revelation to Compilation. Leicester: UK Islamc Academy, 2003.

Azra, Azyumardi. "Menebar Benih Tradisi Baru Islam." In IAIN \& Modernisasi Islam Di Indonesia, edited by Fuad Jabali and Jamhari. Jakarta: Logos, 2002.

Husaini, Adian. Hegemoni Kristen-Barat Dalam Studi Islam Di Perguruan Tinggi. Jakarta: Gema Insani Press, 2006.

- "Hermeneutika Dan Infiltrasi Kristen." Last modified 2004. Accessed October 4, 2016. http://www.hidayatullah. com/kolom/catatan-akhir-pekan/ $\mathrm{read} / 2004 / 04 / 03 / 2486 /$ hermeneutika-daninfiltrasi-kristen.html.

. "Kajian Orientalis Di UIN Jakarta." Last modified 2006. Accessed January 1, 2016. http://faisal-wibowo.blogspot. com/2013/01/kajian-orientalis-di-uinjakarta.html.

- "Problem Teks Bible Dan Hermeneutika." Islamia 1, no. 1 (2004).

_. Virus Liberalisme Di Perguruan Tinggi Islam. Jakarta: Gema Insani Press, 2009. Wajah Peradaban Barat: Dari Hegemoni
Kristen Ke Dominasi Sekular-Liberal. Jakarta: Gema Insani Press, 2005.

Iqbal, Muzaffar, ed. Integrated Encyclopedia of the Qur'ān (IEQ). Sherwood Park, Seatlle: Center for Islamic Sciences, 2013.

- 'Integrated Encyclopedia of the Qur'ann: Raison D'etre \& Project Summary." Islam \& Science 8, no. 1 (2010): 33-47.

__. "Introduction." Integrated Encyclopedia of the Qur'ān (2013): xi-xix.

. "The Qur'an and Its Disbeliever." Islam \& Science 7, no. 2 (2009): 87-126.

- "The Qur'ān, Orientalism, and the Encyclopaedia of the Qur'ann." Journal of Qur'anic Research and Studies 3, no. 5 (2008): 5-45.

Karimi-Nia, Morteza. “Contemporary Qur'anic Studies in Iran and Its Relationship with Qur'anic Studies in the West." Journal of Qur'anic Studies 14, no. 1 (2012): 45-72.

Koç, Mehmet Akif. "The Influence of Western Qur'anic Scholarship in Turkey.” Journal of Qur'anic Studies 14, no. 1 (2012): 9-44.

Koren, J., and Y.D. Nevo. "Methodological Approaches to Islamic Studies.” Der Islam 68 (1991): 87-107.

Leaman, Oliver. "The Corpus Coranicum Project and the Issue of Novelty." Journal of Qur'anic Studies 15, no. 2 (2013): 142-148.

Manzoor, S. Parvez. "Method Against Truth: Orientalism and Qur'anic Studies." Muslim World Book Review 7 (1987): 33-49.

- "Method against Truth: Orientalism and Qur'anic Studies." In The Qur'ān: Style and Content, edited by Andrew Rippin, 381-397. Aldershot; Burlington; Singapore; Sydney: Ashgate Variorum, 2001. 
McAuliffe, Jane Dammen, ed. Encyclopaedia of the Qur'ān. Vol. I-V. Leiden: Brill, 2001.

, ed. The Cambridge Companion to the Qur'ān. Cambridge, UK; New York: Cambridge University Press, 2006.

Rahman, Fazlur. "Approaches to Islam in Religious Studies: Review Essay." In Approaches to Islam in Religious Studies, edited by Richard C. Martin. Tucson: The University of Arizona Press, 1985.

Rahman, Yusuf. "Survei Bibliografis Kajian Al-Qur'ān Dan Tafsīr Di Barat: Kajian Publikasi Buku Dalam Bahasa Inggris Sejak Tahun 2000an." Journal of Qur'ān and Hadith Studies 4, no. 1 (2015): 103-127.

- "Tren Kajian Al-Qur'an Di Dunia Barat." Studia Insania 1, no. 1 (2013): 1-8.

Reynolds, Gabriel Said. "Introduction: The Golden Age of Qur'ānic Studies?” In New Perspectives on the Qur'ān: The Qur'ān in Its Historical Context 2, edited by Gabriel Said Reynolds, 1-21. New York: Routledge, 2011.

Rippin, Andrew. "Review of Integrated Encyclopedia of the Qur'an, Vol. 1." Journal of American Oriental Society 136, no. 1 (2016): 222-225.

-. "Review of Tafsir: Interpreting the Qur'ān Edited by Mustafa Shah." Journal of Qur'anic Studies (2013): 162-165.

. "The Reception of Euro-American Scholarship on the Qur' an and Tafsìr : An Overview (Editorial Preface)." Journal of Qur'anic Studies 14, no. 1 (April 2012): $1-8$.

"Western Scholarship and the Qur'ān." In Cambridge Companion to the Qur'ān, edited by Jane Dammen McAuliffe, 235251. Cambridge: Cambridge University
Press, 2006.

Rohman, Izza. "New Approaches in Interpreting the Qur'an in Contemporary Indonesia." Studia Islamika 14, no. 2 (2007): 203-264.

Sadeghi, Behnam, and Uwe Bergmann. "The Codex of a Companion of the Prophet and the Qur'ān of the Prophet." Arabica 57 (2010): 343-436.

. "The Codex of a Companion of the Prophet and the Qur'ān of the Prophet. Corrigenda." Arabica 57 (2010): 516-516.

Sadeghi, Behnam, and Mohsen Goudarzi. "Șan'à' 1 and the Origins of the Qur'ān." Der Islam 87, no. 1-2 (2012): 1-129.

Saeed, Abdullah. The Qur'ān: An Introduction. London and New York: Routledge, 2008.

Said, Edward. Orientalism. New York: Vintage Books, 1979.

Shah, Mustafa, ed. Tafsir Interpreting the Qur'an Vol. 1 Part 1: History and Development. London dan New York: Routledge, 2013.

Sirry, Mun'im A. Kontroversi Islam Awal: Antara Mazhab Tradisionalis Dan Revisionis. Bandung: Mizan, 2015.

- "Rekonstruksi Sejarah Teks Alquran." Republika, April 1, 2005.

Varisco, Daniel Martin. Reading Orientalism: Said and the Unsaid. Seattle: University of Washington Press, 2007.

Welch, A.T. “The Kur'ān.” Encyclopaedia of Islam, 2nd Edition, Online (n.d.).

Zarkasyi, Hamid Fahmy. "Barat." Islamia 1, no. 1 (2004): 119.

. "Mendudukkan Orientalis." In Misykat: Refleksi Tentang Islam, Westernisasi \& Liberalisasi. Jakarta: INSISTS, 2012.

. "Tradisi Orientalisme Dan Framework Studi Al-Qur'an.” Tsaqafah 7, no. 1 (2011): 1-30. 